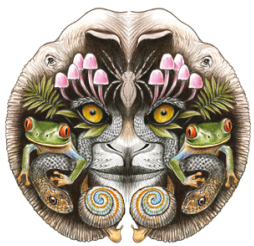

ISSN

Online 0974-7907

Print 0974-7893

OPEN ACCESS

\title{
COMPLEMENTARY METHODS TO ESTIMATE POPULATION SIZE OF Antillean Manatees (SiRenia: TricheChidAe) at CiénAgA de PAREDes, SANTANDER, Colombia
}

\author{
Gloria Katherine Arévalo-González ${ }^{1}$, Delma Nataly Castelblanco-Martínez ${ }^{1,2}$, \\ Pedro Sánchez-Palomino ${ }^{3}$, Hugo Fernando López-Arévalo ${ }^{4} \&$ Miriam Marmontel ${ }^{5}$ \\ 1,2 Fundación Macuáticos Colombia. Calle 27 No 79-167, P.O. Box. 050025, Medellín, Antioquia, Colombia \\ ${ }^{2}$ Oceanic Society. 30 Sir Francis Drake Blvd. P.O. Box 437. Ross, CA 94957, USA \\ ${ }^{3,4}$ Universidad Nacional de Colombia, Ciudad Universitaria, Entrada Calle 53, Edificio 425, \\ P.O. Box 111321, Bogotá D.C., Colombia \\ ${ }^{5}$ Instituto de Desenvolvimento Sustentável Mamirauá, Estrada do Bexiga, 2.584 Bairro Fonte Boa, \\ P.O. Box 38 69470-000 - Tefé (AM) Brazil. \\ ${ }^{1}$ katarevalo@gmail.com (corresponding author), ${ }^{2}$ castelblanco.nataly@gmail.com, ${ }^{3}$ psanchezp@unal.edu.co, \\ ${ }^{4}$ hflopeza@unal.edu.co, ${ }^{5}$ marmontel@mamiraua.org.br
}

Abstract: Information on manatee population size in Colombia is limited. This study was aimed at determining manatee population size in the Ciénaga de Paredes (Colombia) by three different methods: boat-based surveys, side-scan Sonar (SSS) surveys and local interviews. Manatees were counted during breathing events by direct observation during the dry season, with the number of sightings per hour (NSH) and maximum number of simultaneous sightings (MNSS) used as occurrence indices. In 2002, we obtained an average NSH of 27.62 $(S D=12.34)$ and the MNSS was 18; in 2010 the values were 55.71 $(S D=29.79)$ and four respectively. Using linear-transect SSS data we estimated a population size of 12 individuals ( $\% C V=27.3)$. The local community claimed that no hunting or entanglements had taken place in the area for over 20 years. These methods have pros and cons in terms of investment, effort, efficiency and community involvement, and their efficiency may vary in different seasons. Applying them in a complementary way and at greater spatial and temporal scales could enhance the accuracy of results.

Keywords: Ciénaga de Paredes, distance sampling, population size, side-scan sonar, Trichechus manatus.
Manatees (Trichechus spp.) are herbivorous and aquatic, representing the largest continental mammals of South America (Emmons 1990). The three extant species are listed as "Endangered" (EN) according to the IUCN (Self-Sullivan \& Mignucci-Giannoni 2008). In Colombia, the Antillean Manatee (Trichechus manatus) is distributed in the Atrato, Sinú, San Jorge, Cauca, Cesar, Magdalena, Meta and Orinoco river basins (Montoya-Ospina et al. 2001) and populations have rapidly decreased in most of these areas, mainly due to hunting (Trujillo et al. 2006). The Magdalena riparian system and tributaries represent the largest manatee habitat available (Montoya-Ospina et al. 2001), including Ciénaga de Paredes, a wide marsh where one

DOI: http://dx.doi.org/10.11609/JoTT.03156.5830-7 | ZooBank: urn:Isid:zoobank.org:pub:660F8E7A-577D-48AE-9816-840A8BF1C5FF

Editor: Antonio A. Mignucci-Giannoni, Universidad Interamericana de Puerto Rico, San Juan, Puerto Rico Date of publication: 26 June 2014 (online \& print) Manuscript details: Ms \# 03156 | Received 10 April 2012 | Final received 26 February 2014 | Finally accepted 02 June 2014

Citation: Arévalo-González, G.K., D.N. Castelblanco-Martínez, P. Sánchez-Palomino, H.F. López-Arévalo \& M. Marmontel (2014). Complementary methods to estimate population size of Antillean Manatees (Sirenia: Trichechidae) at Ciénaga de Paredes, Santander, Colombia. Journal of Threatened Taxa 6(6): 5830-5837; http://dx.doi.org/10.11609/JoTT.o3156.5830-7

Copyright: (C) Arévalo-González et al. 2014. Creative Commons Attribution 4.0 International License. JoTT allows unrestricted use of this article in any medium, reproduction and distribution by providing adequate credit to the authors and the source of publication.

Funding: Supported by the Alejandro Ángel Escobar Foundation (Colombia Biodiversa Grant Program); Instituto de Desenvolvimento Sustentável Mamirauá; Universidad Nacional de Colombia and Fundación Macuáticos Colombia.

Competing Interest: The authors declare no competing interests.

Acknowledgements: We would like to thank the communities of Campo Duro and El Cerrito for their involvement and help during the field work. The Corporación Autónoma de Santander (CAS) and organization Cabildo Verde- Sabana de Torres also provided support in-kind during our visits. This study was part of the Biologist thesis of Gloria Katherine Arévalo-González at Universidad Nacional de Colombia (2010). Surveys during 2002 were conducted by Delma Nataly CastelblancoMartínez with the support of Omacha Foundation and Sirenian International (Small Grants Program). Thanks for the valuable help in field work are due to Juan Pablo Giraldo and Belkis Aguilar (in 2002); and Gonzalo Pinilla-Buitrago (in 2010). Special thanks to the reviewers of the text and its English translation.
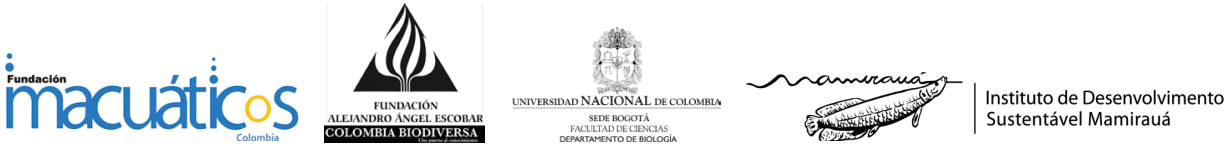
of the better-conserved populations of $T$. manatus in Colombia remains (Magdalena Basin) (Montenegro 1995; Castelblanco-Martínez et al. 2005). Thus, great importance has been placed upon defining priority areas and biological characterization of the wild population in the Magdalena Basin by the National Management and Conservation Program of Manatees in Colombia (Caicedo-Herrera et al. 2005).

According to the Regional Management Plan for the West Indian Manatee (UNEP 2010), a detailed examination of distribution zones and abundance of manatees in Colombia is especially important. However, studying wild manatees in South America is a difficult task due to the species' cryptic habits and low population densities (Paludo 1998). Additionally, manatees in Colombia live in coastal lagoons, creeks, swamps, rivers and floating meadows. These environments typically exhibit low water transparency and are associated with dense riparian vegetation. Although aerial surveys can be a useful method of assessing sirenian population distribution and abundance, they can be logistically difficult and expensive (Reynolds et al. 2012) and may not be appropriate. Therefore, the use of traditional techniques of manatee counting (in Colombia) may often be constrained by limited visibility, lack of good access routes to the study sites and budget limitations to capture individuals. Consequently, it is necessary to come up with innovative and viable techniques for tracking cryptic aquatic species in the country.

In areas such as the Amazon and Orinoco basins - where forest canopy and extreme seasonal water level changes make strategies such as aerial surveys ineffective (Castelblanco-Martínez et al. 2003) - a combination of boat and land-based surveys have been used to monitor manatee distribution and abundance (Aragones et al. 2012). Previous research has suggested that Side-Scan Sonar (SSS) can also be used to detect free-ranging manatees in clear, turbid and tanninstained waterways - showing detection rates ranging between 70-95 \% (Gonzalez-Socoloske et al. 2009). Finally, interviews with local communities provide significant information and have been recognized as a valuable source of ecological data regarding distribution, migration, feeding habits and reproduction of manatees (Franzini et al. 2013). However, despite these survey protocols representing a cost-effective means for addressing a wide range of research applications to small and medium spatial extents (Aragones et al. 2012), all of them have limitations. This study compares and combines three manatee survey methods to determine population size of Antillean manatees in the Ciénaga de
Paredes during the dry season.

\section{METHODS}

Study site: Ciénaga de Paredes $\left(7^{0} 26^{\prime} \mathrm{N} \& 73^{\circ} 45^{\prime} \mathrm{W}\right)$ is located between the municipalities of Puerto Wilches and Sabana de Torres in the north-east of Santander (75m elevation) (Figs. 1,2). This large marsh covers approximately 1.776ha (IGAC 1985) and is connected indirectly to the river (Marsh Type 3 according to Arias 1985). The mean depth of Ciénaga de Paredes ranges between $4 \mathrm{~m}$ during the wet season (August to October) and $0.9 \mathrm{~m}$ during the dry season (December to March) (Castelblanco-Martínez et al. 2005). Information from local inhabitants reveal that manatees spend the most critical part of the dry season in Los Pozos - a reduced 0.37ha area within the Ciénaga de Paredes. Furthermore, in this area a unique interaction of local communities and manatees has been reported: Every summer local fishermen voluntarily make artificial feeders - consisting mainly of water hyacinth (Eichhornia crassipes) and water grass (Paspalum repens) - for the manatees (Image 1; Fig. 3). These feeders are continuously enriched by the fishermen and kept until the beginning of the rainy season.

Boat-based visual surveys: Boat-based surveys from a fixed point were conducted through continuous, ad libitum observations at Los Pozos during the dry seasons of 2002 and 2010. Individuals were detected - as described by Castelblanco-Martínez et al. (2009) - through exposure of body parts such as the snout (during breathing), the back or tail. Seven 60-min observation periods were conducted by two observers. During each observation period the data shown below were recorded: date, hour, observer, manatee position, maximum number of simultaneous sightings (MNSS), number of sightings per hour (NSH), number of calves, presence of boat traffic and food amount in the artificial feeders. Calves were identified by their smaller size and the close proximity to a larger individual. A 'sighting' was defined as an event when one or more manatees were observed. All manatees in sight were considered as a group

The NSH and the MNSS were considered relative indices of occurrence. Manatees usually breathe simultaneously when they are in a group (Hartman 1979; Castelblanco et al. 2009) and so the MNSS was assumed as the minimum size of the group. Additional boat-based surveys were conducted in other areas of Ciénaga de Paredes as well as in Caño Peruétano and Quebrada la Gómez, where observers searched for manatees and/or evidence of manatee presence (feces and feeding tracks 


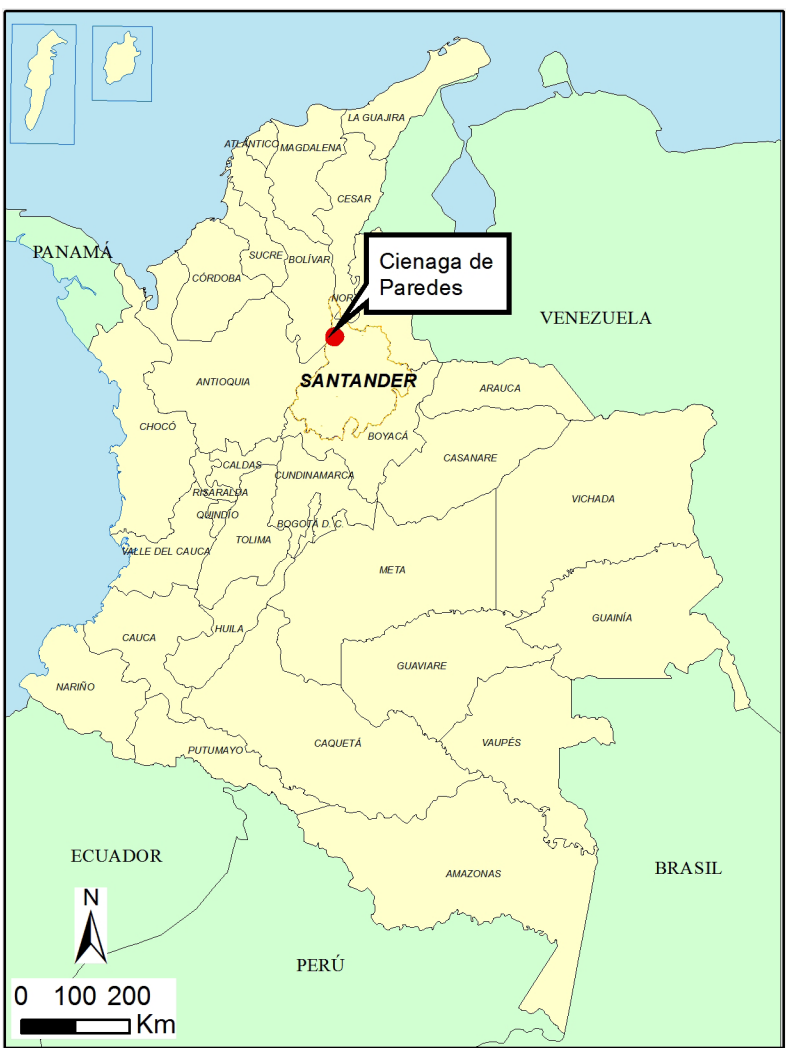

Figures 1-2. Study site. (1) - Colombia; (2) - Ciénaga de Paredes.

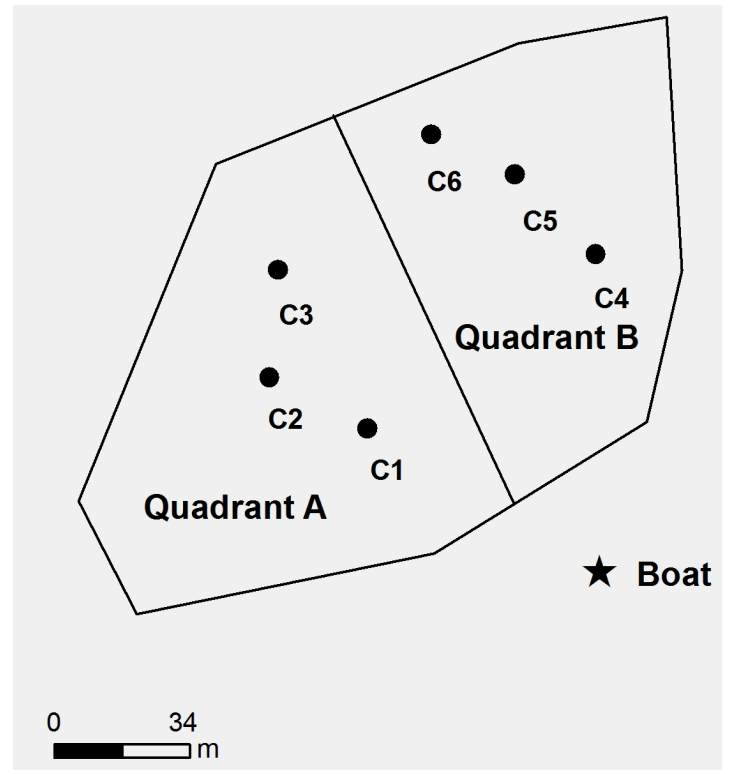

Figure 3. Los Pozos: Quadrants and Artificial Feeder observation points $\mathrm{C} 1-\mathrm{C} 6$.

on riparian vegetation).

Boat-based SSS surveys: In 2010 in Los Pozos, Caño Peruétano and Quebrada la Gómez, linear boat surveys
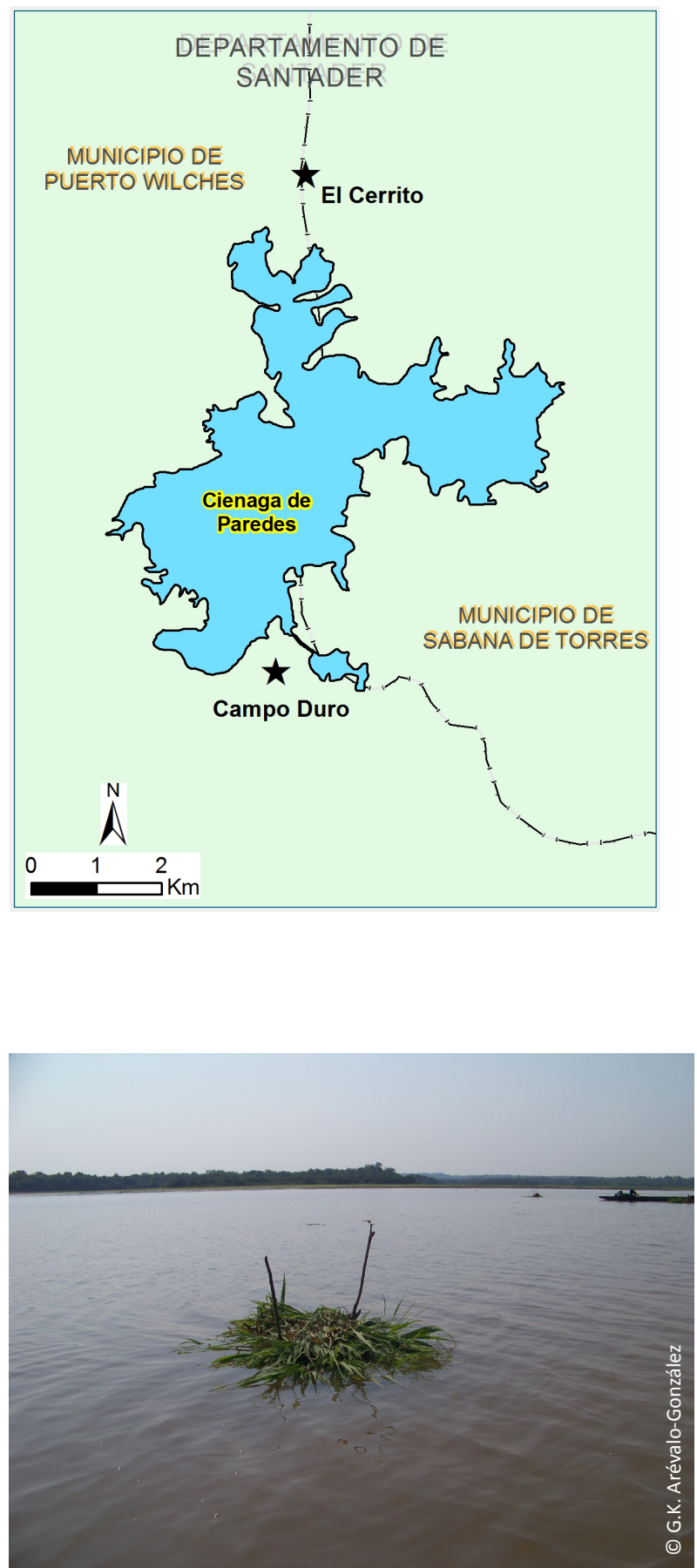

Image 1. Artificial feeders

- as described by Gerrodette \& Taylor 2000 - were conducted using a Humminbird 997c SI COMBO Side-Scan Sonar. Surveys were performed using a non-motorized boat at 3-4 km/h. SSS systems function by emitting a narrow fan-shaped pulse at a wide-angle perpendicular to the movement of the sensor (Gonzalez-Socoloske \& Olivera-Gomez 2012). The signal is then translated through a computer into a digitized image to display a 
continuous reading (Gonzalez-Socoloske et al. 2009). Using SSS it is possible to assess the distance, position, size and composition of an object at hand (Anonymous 2008). SSS also provides additional ambient information such as water surface temperature, habitat data (i.e., bottom substrate type, texture and depth) and location (built-in GPS) (Aragones et al. 2012). The transects were arbitrarily established and measured using Google Earth, while the width was standardized according to the clarity of the image of the bottom given by the SSS. The manatees were identified following Gonzalez-Socoloske et al. (2009) and Gonzalez-Socoloske \& Olivera-Gomez (2012), with additional consideration towards the effect of density and position upon object shadows. Deep View V2.2 (Anonymous 2010) was used to visualize data recorded by the SSS and determine the distance of each animal to the transect.

The software Distance 6.0 (Thomas et al. 2009) was used to determine the population size. The program is based on the Fourier series of probability for the density function $f(x)$. Densities were estimated using the equation:

$$
D=\frac{n \cdot f(0)}{2 \cdot L}
$$

where $D=$ estimated population density, $n=$ number of animals seen over the transect and $L=$ length of the transect. The perpendicular distance $(A)$ was calculated by:

$$
A=C \cdot \sin B
$$

Where $\mathrm{C}=$ the distance between the animal and the observer and $\mathrm{B}=$ the angle between $\mathrm{C}$ and the transect line (Tapia et al. 2002).

The detection probability was estimated from seven models combining density and probability functions (uniform, half-normal and hazard-rate) with adjustments (cosine, simple-polynomial and Hermite-polynomial) and the one with the lowest delta Akaike information criterion (dAIC) was chosen (Akaike 1985; Thomas et al. 2010).

Social survey: Semi-structured interviews were conducted with people from the two nearest communities to Ciénaga de Paredes (Campo Duro and El Cerrito) during 2002 and 2010. In 2002, the interviews were addressed only to adult fishermen with some knowledge about the species, while in 2010 there were no set criteria for choosing the population sample to be interviewed. Free-flowing formulation and open questions were used, allowing flexibility in the exchange of knowledge and preventing the answers from being forced. Each interview was allocated a code according to the year and organized alphabetically. The responses were organized and the data triangulated. Triangulation consisted of the combination of different sources of data in an attempt to mitigate the psychological factor from the answers (Lambert \& Loiselle 2008). Data were then compared and complemented to avoid duplication and to minimize the error. The information was then analyzed descriptively using exploratory graphics.

\section{RESULTS}

Boat-based visual surveys: A total of 50.17 hours of boat-based survey was conducted at Los Pozos; 14 hours from a fixed point ( $7 \mathrm{~h}$ in each year) and 36.17 of transects (24h in 2002 and 12h in 2010) (Table 1). The direct, fixed-point observations from the boat resulted in average NSH of $27.62(S D=12.34)$ and 55.71 $(S D=29.79)$ for each year. The MNSS was 17 (2002) and 4 (2010), while no individuals were observed during boat

\begin{tabular}{|c|c|c|c|c|c|c|}
\hline Year & Method & Effort (h) & NSH (SD) & MNSS & MNSS/h & Calves \\
\hline \multirow{3}{*}{2002} & Boat-based survey (Fixed point) & 7 & $27.62(12.34)$ & 18 & 2.57 & 4 \\
\hline & Boat-based survey (Transect) & 24 & 0 & 0 & 0 & 0 \\
\hline & Interview $(n=35)$ & 17.5 & NA & $30^{*}$ & NA & NA \\
\hline \multirow{5}{*}{2010} & Boat-based survey (Fixed point) & 7 & $55.71(29.79)$ & 4 & 0.57 & 2 \\
\hline & Boat-based survey (Transect) & 12 & 0 & 0 & 0 & 0 \\
\hline & Side-Scan Sonar & 1 & 12 & 12 & 12 & 2 \\
\hline & Interview $(n=16)$ & 8 & NA & $20^{*}$ & NA & NA \\
\hline & & Total: 76.5 & Mean: 41.66 & Minimum**:18 & & Minimum: 4 \\
\hline
\end{tabular}

Table 1. Manatee population size in Ciénaga Paredes obtained through different methods. An average of $\mathbf{3 0}$ min per interview was assumed.

* - Mode; ** - Not considering the interviewees estimates; NA - Data no available; NSH - number of sightings per hour; SD - Standard Deviation; NSH - number of sighting per hour; MNSS - minimum number of simultaneous sightings, interpreted as the minimum number of individuals in a group; Sighting: an event when a manatee or a group of manatees sharing a space is observed. 
transects. A total of nine signs of feeding were recorded in 2002, on patches of Paspalum fasciculatum, P. repens and Polygonum ferrugimeum. In 2010, only one feeding sign was sighted in a patch of $P$. repens.

Boat-based SSS survey: The survey effort using the SSS was 5.15 hours and included one transect in Caño Peruétano and seven transects in Los Pozos. The transects were all $20 \mathrm{~m}$ wide, $5.5 \mathrm{~km}$ long at the Caño and 0.04-0.09 km long in Los Pozos. A total of 49 manatee detections were registered in Los Pozos while no records were obtained in the Caño Peruétano. According to the analysis, the estimated population in Los Pozos is 12 individuals. The highest number of individuals detected in a transect was 12 and the minimum was two.

Social survey: 32 and 25 interviews were conducted during 2002 and 2010 respectively. All of those interviewed in 2002 were men, while in 2010 both men (64\%) and women (36\%) from the community were interviewed. The majority of those interviewed were aged between 21 and 40 years old. Most of the interviewees lived in El Cerrito (74.3\% in 2002 and 52\% in 2010) and in Campo Duro (11.4\% in 2002 and 48\% in 2010) and only two interviewees lived in Caño Peruétano (2002). The majority of interviewees had lived in their respective area for $11-15$ years (15.6\% in 2002 and $16 \%$ in 2010). However, when looking at the data separately, the largest category in 2002 (25\%) had been resident for 0-5 years and in 2010 (20\%) had been resident for 2125 or 41-45 years. The knowledge of the species -in the majority of cases-came from sightings (66\% in 2002 and $48 \%$ in 2010), although some people are familiar with the species from sightings and consumption (19\% in 2002 and $40 \%$ in 2010).

When asking the people for the number of manatees in the Ciénaga de Paredes only 87.5\% (2002) and 64\% (2010) gave an estimate, which ranged between 15 and 100 individuals (mode: 30 for 2002 and 20 for 2010).
In 2002, the average local estimate of the manatee population was 38.3 individuals ( $S D=17.1$ ). $40.6 \%$ of the interviewed population believed the population to be increasing, 31.3\% believed it to be decreasing and $6.3 \%$ believed that it had remained the same for the past 20 years. By 2010 the average population estimate was 30.3 individuals $(S D=20.5$ ) where $20 \%$ of locals believed the manatee population was increasing and $76 \%$ believed it was decreasing.

Regarding the perception of the state of manatee conservation in 2002, $28.6 \%$ were optimistic and $68.6 \%$ were pessimistic about it. This changed in 2010 when $56 \%$ had optimistic opinions and $16 \%$ were pessimistic.

\section{DISCUSSION}

Methodological Considerations: Boat-based visual surveys from fixed points had the advantage of being inexpensive in terms of fuel consumption, but this method requires a considerable amount of human effort to detect manatees (Table 2). Experience, physical exhaustion and visual capabilities can vary considerably between observers during visual surveys and thus influence the data gathered. Furthermore, the number of observers affects the potential area of observation. NSH values obtained in this research were high, when compared with previous studies in Colombia (AguilarRodríguez 2003; Rojas-Rojas 2005; Guerrero \& Lugo 2007; Farías-Curtidor 2008; Castelblanco-Martínez et al. 2009). This may a result of the manatees' confinement in 'Los Pozos', which facilitated the identification of most of their surface activities. We failed to find manatees by boat-based transects, which also require a considerable investment of fuel. Though it may be useful when surveying an extended area, for punctual population size assessment-as in the Ciénaga de Paredes case-this method proved to be inefficient. However, it was the only reliable method in detecting

Table 2. Pros-cons analysis of methods used to count manatees in Ciénaga de Paredes.

\begin{tabular}{|l|c|c|c|c|c|}
\hline & $\begin{array}{c}\text { Short-term } \\
\text { investment }\end{array}$ & $\begin{array}{c}\text { Long-term } \\
\text { investment }\end{array}$ & $\begin{array}{c}\text { Efficiency } \\
\text { (NSH/h) }\end{array}$ & $\begin{array}{c}\text { Efficiency } \\
\text { (MNSS/h) }\end{array}$ & $\begin{array}{c}\text { Community } \\
\text { involvement }\end{array}$ \\
\hline Boat-based survey (fixed point) & G & P & E & G & P \\
\hline Boat-based survey (transect) & P & B & B & B & G \\
\hline Boat-based SSS survey & B & G & G & E & $B$ \\
\hline Interviews & E & E & --- & P & E \\
\hline
\end{tabular}

Categories: Excellent - E, Good - G, Poor - P, Bad - B.

Interviews require very low economic investment, while all boat-based surveys incur fuel expenses. The initial investment is even higher when an SSS is included in the budget. In the long term however, boat-based transects are more expensive because they require more effort in time and fuel. The efficiency in NSH/h obtained through surveys from fixed points is higher because all breathing moments are counted regardless of whether the same animal is identified or not. However the SSS proved to be more efficient in counting the total number of individuals (or MNSS) per unit time: in fact, it was possible to assess the number of individuals after only one hour of SSS survey. All methods imply the involvement of local people at various levels though the use of SSS does not require good local knowledge and would be beneficial where less community involvement is available. 
manatee feeding tracks and should be considered during rising and high-water seasons, when the manatees spread out and can be detected almost exclusively by feeding signs.

Although the SSS is relatively costly equipment, this method showed the best cost-benefit balance in the long term. The initial investment is, therefore, compensated by the reduction in gasoline expenses, sampling time and field assistants. Other advantages include the absence of human bias on direct observations and the possibility of covering larger areas in a short time, resulting in a higher efficiency. The SSS produces a digital record of the sampling events, which improves the reliability of the analysis and enables the analysis to be performed away from the field site. The data obtained with the SSS can be applied to models for estimating population size and the results optimized. In contrast, the information gathered from direct sightings is limited to inferring presence or absence and determining relative abundance indices such as the MNSS. Nevertheless, direct observations enable the collection of other valuable information such as age classes, behavior and even particular characteristics of individuals (CastelblancoMartínez 2004). The efficiency of SSS was facilitated by the drought season conditions, when the marsh water has the lowest levels and manatees congregate in the deepest areas. Previous studies have also gathered information from other manatee populations that form compulsory groups under stressful environmental conditions (Bermúdez-Romero 2003). It is expected that during the winter the probability of encountering manatees diminishes as they move toward flooded areas. Moreover, the use of motorized boats can cause the animals to flee. For instance it was noted, despite local reports of manatee presence in the Caño Peruétano channel, that the SSS was not able to detect them at that place and time. Therefore the major disadvantage of the SSS method is related to difficulties associated with linear displacement at low speed, as reported by Gonzalez-Socoloske et al. (2009). When using the SSS it is important to conduct preliminary observations of the bottom in order to eliminate possible sources of error (logs, rocks etc.). Other factors to be aware of are the depth of the water - since this determines the SSS capacity for reaching and receiving signals, the position of the transducer with respect to the boat engine in order to avoid interference in the images and, lastly, the duration of the battery, which can limit the immediate sampling time. Using SSS implies a minimum of training before actually carrying out the survey.

The values of population size obtained through interviews were significantly higher (almost double) than those obtained by more rigorous methods. Estimations of manatee numbers were smaller in 2010 than in 2002. This could be a result of including interviewees the 2010 survey who were not necessarily familiar with the species. Other factors include the possibility of real change in population size. Values given by fishermen can be biased by a number of human factors. Interviewees may choose to hide information or alternatively, exaggerate or invent information to impress the interviewer (Franzini et al. 2013). Although interviews are not recommended as an accurate method to assess population size, other information, such as gross population trends (increasing, decreasing, stable), can be obtained and might provide a good indication of the manatee conservation status. The interviews were inexpensive in comparison with the other methods and allowed gathering information not only about population size but also on many other biological and cultural issues of the manatees in Ciénaga Paredes.

Implications for conservation: The Ciénaga de Paredes area has a major advantage compared to other sites previously studied in Colombia, which is the absence of hunting or any other direct threat of human consumption or trade. Also, the level of awareness of the surrounding community was evident during the interviews. According to the most optimistic interviewers, the manatee population is stable or increasing. Their reasons for supporting this hypothesis were:

i) Local residents do not attack, chase or kill manatees for consumption or any other reason.

ii) The numbers of manatees found dead or injured are not excessive.

iii) New calves are sighted every summer

During several captures for health assessment and marking, fishermen have never captured the same animal twice. However, the community did express its concern about the sources of pollution in the Ciénaga de Paredes, which may consequently affect the survival of manatees, particularly during the summer when evidence indicates increasingly drastic effects.

\section{RECOMMENDATIONS}

It seems clear from the interviews that in descending waters manatees migrate to Los Pozos through the Caño Peruétano. In order to describe the movement dynamic of manatees throughout the year, surveys at different seasons are recommended. Manatees in Cienaga Paredes may be effectively counted during the drought by SSS, although a combination of methods would provide more 
accurate results. This is especially important in the wet seasons, when the efficiency of SSS can be jeopardized by the displacement of the manatees, diminishing their detectability. All techniques to identify and count manatees under the Ciénaga de Paredes conditions have limitations. We strongly recommend standardizing the complementary use of them in order to reach an ideal balance between economic investment, field effort, community involvement and accuracy of results. The species protection by this local community is a unique condition of human-manatee interaction in Colombia due to the lack of hunting, care during high risk times and the creation of civil associations that regulate and encourage these activities. Despite the presence of human bias and its lack of power to rigorously assess population size, contact with the local community is indispensable for future management plans in Ciénaga de Paredes and therefore, must be considered during any research.

\section{REFERENCES}

Aguilar-Rodríguez, B. (2003). Distribución, conservación y uso de hábitat del manatí Antillano (Trichechus manatus manatus) en la Depresión Momposina. Bachelor Thesis. Facultad de Ciencias, Universidad Pedagógica y Tecnológica de Colombia, vii+100pp.

Akaike, H. (1985). Prediction and entropy, pp. 1-24. In Atkinson, A.C \& S.E. Fienberg. (eds.). A Celebration of Statistics. Springer-Verlag, New York.

Anonymous (2008). Installation and Operations manual Hummindbird 997c SI COMBO. Hummindbird, Eufaula AL, USA, 300pp.

Anonymous (2010). DeepView FV Version 2.2. <http://deepvision. se/>. Downloaded 20 January 2010.

Aragones, L.V., K. LaCommare, S. Kendall, D.N. Castelblanco-Martínez \& D. González-Socoloske (2012). Boat and land-based surveys, In: Hines, E., J. Reynolds, L. Aragones, A.A. Mignucci-Giannoni \& M. Marmontel (eds.). Sirenian Conservation: Issues and Strategies in Developing Countries. University of Florida Press, 326pp.

Arias, P. (1985). Las ciénagas en Colombia. Revista Divulgación Pesquera. Inderena 22: 39-70.

Bermúdez-Romero A.L. (2003). Presencia y uso diferencial del hábitat de Trichechus manatus en el río Orinoco, zona de influencia de Puerto Carreño, Vichada. Colombia. Una visión biológica y cultural. Bachelor Thesis. Facultad de Ciencias Naturales, Universidad Jorge Tadeo Lozano, 403pp.

Caicedo-Herrera, D. Trujillo, F. Rodriguez, C.L. \& M, Rivera (eds.). (2005). Programa nacional de manejo y conservación de manatíes (Trichechus sp.) en Colombia. Ministro de Ambiente, Vivienda Desarrollo Territorial [MAVDT]; Fundación Omacha, Bogotá, 176pp.

Castelblanco-Martínez, D.N. (2004). Estudio del comportamiento en vida silvestre del manatí del Orinoco (Trichechus manatus), pp. 113131. In: Diazgranados, M.C. \& F. Trujillo (eds.). Estudios de fauna silvestre en ecosistemas acuáticos en la Orinoquia Colombiana. Fundación Javeriana de Artes Gráficas, Bogotá, Colombia, 403pp.

Castelblanco-Martínez, D.N., F.C.W. Rosas, A. Bermudez \& T. TrujilloGonzález (2003). Conservation status of the West Indian Manatee, Trichechus manatus manatus in the Middle Orinoco (Vichada, Colombia). In: $15^{\text {th }}$ Biennial Conference on the Biology of Marine Mammals. North Carolina, USA, 30pp.

Castelblanco-Martínez, D.N., V. Holguín \& J.M. Zapata (2005) Conservación y manejo del manatí en la Ciénaga de Paredes
(Santander), pp. 105-113. In: Caicedo-Herrera, D., F. Trujillo, C.L. Rodriguez \& M. Rivera (eds.). Programa nacional de manejo y conservación de manatíes (Trichechus sp.) en Colombia. Ministro de Ambiente, Vivienda Desarrollo Territorial [MAVDT]; Fundación Omacha, Bogotá, 176pp.

Castelblanco-Martínez, D.N., A.L. Bermúdez-Romero, I.V. GómezCamelo, F.C. Weber, F. Trujillo \& E. Zerda-Ordoñez (2009). Seasonality of habitat use, mortality and reproduction of the vulnerable Antillean Manatee Trichechus manatus manatus in the Orinoco River, Colombia: implications for conservation. Oryx 43(2): 235-242; http://dx.doi.org/10.1017/S0030605307000944

Emmons, L.H. (1990). Neotropical Rainforest Mammals: A Field Guide. The University of Chicago Press, Chicago, USA, 307pp.

Farías-Curtidor, N.E. (2008). Distribución del manatí Trichechus manatus manatus y percepción de la comunidad local con respecto a la especie en la cuenca media y baja del Río Atrato (Chocó, Colombia). Bachelor Thesis. Facultad de Ciencias, Pontificia Universidad Javeriana, 108pp.

Franzini, A., D.N. Castelblanco-Martínez, F.C.W. Rosas \& V.M.F. Da Silva (2013). What do local people know about Amazonian manatees? Traditional Ecological Knowledge of Trichechus inunguis in the Oil Province of Urucu, AM, Brazil. Brazilian Journal of Nature Conservation 11(1):77-82; http://dx.doi.org/10.4322/ natcon.2013.012

Gerrodette, T. \& B.L. Taylor (2000). Estimación del tamaño de la población, pp. 78-82. In: Eckert, K.L., K.A. Bjorndal, F.A. AbreuGrobois \& M. Donnelly (eds). Técnicas de investigación y manejo para la conservación de las Tortugas Marinas. Marine Turtle Specialist Group UICN/CSE, Pennsylvania, USA, 265pp.

González-Socoloske, D., L.D. Olivera-Gómez \& R.E. Ford (2009). Detection of free ranging West Indian manatees Trichechus manatus using side-scan sonar. Endangered species research 8: 249-257; http://dx.doi.org/10.3354/esr00232

Gonzalez-Socoloske, D. \& L.D. Olivera-Gomez (2012). Gentle giants in dark waters: using side-scan sonar for Manatee research. The Open Remote Sensing Journal 5: 1-14;

Guerrero, V.L. \& A.F. Lugo (2007). Análisis del estado de la población de manatí Trichechus manatus manatus Linnaeus, 1758 (Mammalia: Sirenia) en la Vía Parque isla de Salamanca, (Magdalena-Colombia). Bachelor Thesis. Facultad de Ciencias, Universidad de Tolima, Ibagué, Colombia.

Hartman, D.S. (1979). Ecology and behavior of the manatee (Trichechus manatus) in Florida. The American Society of Mammalogists, Special Publication No.5. Ithaca, USA, 153pp.

Instituto Geográfico Agustín Codazzi [IGAC] (1985). Santander, Aspectos Geográficos. IGAC, Bogotá, Colombia 70pp.

Lambert, S.D. \& C.G. Loiselle (2008). Combining individual interviews and focus groups to enhance data richness. Journal of Advanced Nursing 62(2): 232-237; http://dx.doi.org/10.1111/j.13652648.2007.04559.x

Montenegro, M. (1995). Evaluación ambiental de la Ciénaga de Paredes, Sabana de Torres, Santander, como hábitat para fauna silvestre, con especial énfasis en el manatí (Trichechus manatus). Fundación para la Promoción de la Investigación y la Tecnología Inderena, Bogotá, 74+14pp.

Montoya-Ospina, R.A., D. Caicedo-Herrera, S.L. Millán-Sánchez, A.A. Mignucci-Giannoni \& L.W. Lefebvre (2001). Status and distribution of the West Indian Manatee, Trichechus manatus manatus, in Colombia. Biological Conservation 102: 117-129; http://dx.doi. org/10.1016/S0006-3207(00)00062-8

Paludo, D. (1998). Estudos sobre ecologia e conservação do peixeboi marinho (Trichechus manatus manatus) no Nordeste do Brasil. Instituto Brasileiro do Meio Ambiente e dos Recursos Naturais Renováveis, Brasília, 68pp.

Reynolds, J., B. Morales-Vela, I. Lawler \& H. Edwards (2012). Utility and Design of Aerial Surveys for Sirenians, pp. 186-195. In: Hines, E., J. Reynolds, L. Aragones, A.A. Mignucci-Giannoni \& M. Marmontel (eds). Sirenian Conservation: Issues and Strategies in Developing Countries. University of Florida Press, 326pp 

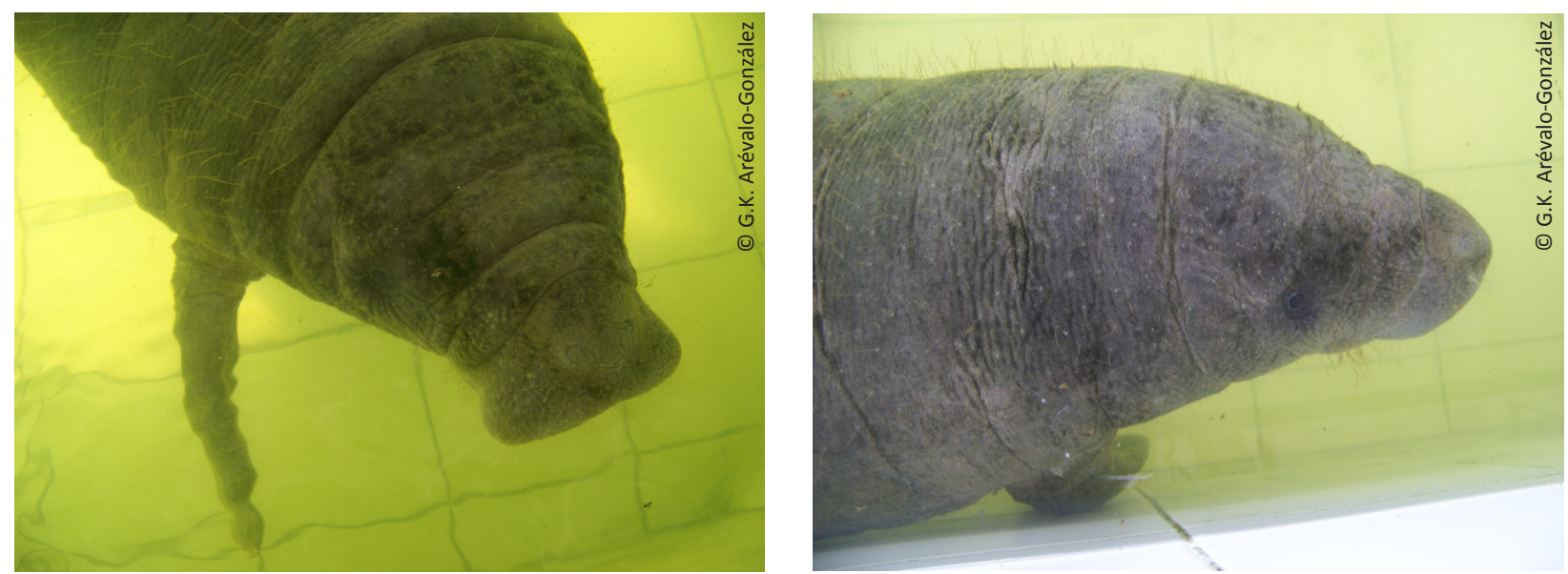

Appendix 1. María del Mar, manatee in captivity (2010) 8-month old. in Lorica, Córdoba, Colombia.

Rojas-Rojas, D. (2005). Distribución, alimentación y problemas de conservación del manatí antillano Trichechus manatus manatus en la cuenca baja del Río Sinú, Departamento de Córdoba. Bachelor Thesis. Facultad de Ciencas Básicas, Universidad Nueva Granada, Bogotá, xvi+135pp.

Self-Sullivan, C. \& A. Mignucci-Giannoni (2008). Trichechus manatus ssp. manatus. In: IUCN 2013. IUCN Red List of Threatened Species. Version $2013.1<$ http://www.iucnredlist.org/details/22105/0> Downloaded 23 August 2013.

Tapia, J., S. Ibarra, G. Mendoza, C. Zaragoza, F. Clemente \& L.A. Tarango (2002). Densidad poblacional de la codorniz noctezuma (Cyrtonyx montezunae) en la región noroeste del estado de México, México. Veterinaria México 33(003): 255-263.

Thomas, L., J.L. Laake, E. Rexstad, S. Strindberg, F.F.C. Marques, S.T. Buckland, D.L. Borchers, D.R., Anderson, K.P. Burnham, M.L. Burt, S.L. Hedley, J.H. Pollard, J.R.B. Bishop \& T.A. Marques (2009). Software: Distance 6.0. Release 2. Research Unit for Wildlife Population Assessment, In: University of St. Andrews, UK. <http:// www.ruwpa.st-and.ac.uk/distance/>. Downloaded on 7 Febrary 2010.

Thomas, L., S.T. Buckland, A.E. Rexstad, J.L. Laake, S. Strindberg S.L. Hedley, J.R.B. Bishop, T.A. Marques \& K.P. Burnham (2010). Distance software: design and analysis of distance sampling surveys for estimating population size. Journal of Applied Ecology 47(1): 5-14; http://dx.doi.org/10.1111/j.1365-2664.2009.01737.x

Trujillo, D.F.C., D.N. Castelblanco-Martínez, S. Kendall \& V. Holguín (2006). Trichechus manatus, pp. 161-166. In: Rodríguez-Maecha, J.V., M. Alberico, F. Trujillo, J. Jorgenson (eds.). Libro Rojo de los Mamíferos de Colombia. Conservación Internacional Colombia, Ministerio de Ambiente, Vivienda y Desarrollo Territorial, Bogotá, Colombia, 402pp.

UNEP (2010). Regional Management Plan for the West Indian Manatee (Trichechus manatus). Compiled by Ester Quintana-Rizzo and John Reynolds III. CEP Technical Report No. 48. UNEP Caribbean Environment Programme, Kingston, Jamaica, 169pp. 